\title{
Cash flow optimization in industrial enterprise
}

\author{
T.N. Myznikova ${ }^{1, *}$, and N.V. Zhdanova ${ }^{1}$ \\ ${ }^{1}$ South Ural State University, Chelyabinsk, Russia
}

\begin{abstract}
Optimization of cash flows of the industrial company provides economic entity necessity and sufficiency of financial resources for sustainable activities. Cash optimization techniques are grouped into two blocks: theoretical - is mainly foreign methods and applied techniques that are mostly used by Russian authors. Models described in the literature are not allowed for the particular industry in the formation of cash. The mathematical models described in the literature do not allow to take into account industry characteristics in the formation of funds. The proposed methodology by authors allows to predict cash amounts based on business company. The balance of cash flows is provided by the budgeting system. The company's the released money can send funds for investment purposes. Effectiveness of confirmed by practical testing methodology on the existing machine-building enterprise.
\end{abstract}

\section{Introduction}

The relevance of cash flow optimization for any business entity is acquiring greater significance under conditions of shortage of production resources, including cash funds.

Cash flow can be generated from various types of activity: operating, financing and investing. Along with this, an amount of flow, its vector and dynamics allow us to solve a variety of tasks, among other things in the interests of different participants of business process.

Cash flows from various activities collide with each other, altogether solving the general problem of industrial enterprise - providing ever-increasing economic benefits. For this reason there is a need to create a model of cash flaw optimization for industrial enterprises that is able to meet production, financial and investment goals.

On the one hand, models of cash flow optimization presented in modern scientific literature do not take into account sectoral affiliation of a business entity, which reduces their credibility and practical significance. And on the other hand, they do not help to identify factors that affect total financial result from their use.

It can be assumed that the system of cash funds budgeting can provide an optimal cash flow ratiofor a machine-building enterprise that is sufficient for its effective operating, investing and financing activities.

\section{Scientific development of thetopic}

Considerable attention to issues of cash flow management has been payed since the second half of $80 \mathrm{~s}$. In the beginning of 21 st century, the number of scientific and practical researches in this area has grown considerably. The USA leadsin the number of researches (in particular, Ohio State University, New York University, University of California, Los Angeles and other North American universities). A significant part of researches is dedicated to management of the cash flow generated by financial investments. To us, particularfeatures of interest present researches of cash funds management in models of multivariate time seriesthat use past values of indicators as explanatory variables in time series of regression [1].

A number of researchers use the factor model to optimize cash flow. In particular, Martins, P. establishes the relationship between the mainresulting indicator - cash funds and factorsthat form it: workforce and production. Along with this, authors combine them into a single system based on monoproduction (production of one type of goods) without reference to the specifics of an industry, which reduces the usefulness of the presented model [2].

In the paper of Chen, W.-N., Zhang, J., Chung, H.S.-H., Huang, R.-Z., Liu, O the change of cash funds value is taken into account and discounting is introduced. The practical component of the proposed mathematical modeling is a multi-dimensional assessment of analyzed factors. However, even this authors' approach does not take into account the effect on the result of internal factors, such as lack of liquidity, while considering cash flow over time [3].

Works of Russian authors that address the problem of cash flow optimization in enterprises can be classified into two parts. The first one represents works of a theoretical nature. These include works the economic analysisfounders of the Soviet and post-Soviet period (Savitskaya, Kovalev, Sheremet, Lukasiewicz [4-7]), the second one represents works of an applied nature, includingworks that take into account sectorial specificity.They are much rarer. Works of Sanakoev E.V., Novolodsky D.A., Sinkina A.A. are noteworthy $[8,9,10]$. Along with this, these authors view cash flow without reference to relationship between all activities and industry specifics. 
Table 1. Factors of changesin net cash flow (NCF) for current operations12.

\begin{tabular}{|c|c|c|c|}
\hline \multicolumn{4}{|c|}{ Factors of changes } \\
\hline Increase of NCF & Decrease of NCF & Factor model & Comment \\
\hline Growth of net profit & Decrease in net profit & \multirow[t]{2}{*}{$\Sigma\left[V M P_{i}\left(P_{i}-C P_{i}\right)\right]$} & $\begin{array}{l}V M P_{i}-\text { volume of manufactured production, } \\
\text { goods, services; }\end{array}$ \\
\hline Decrease in losses & Increase in losses & & $\begin{array}{c}P_{i}-\text { price of realization; } \\
C P_{i}-\text { cost price of manufactured good }\end{array}$ \\
\hline $\begin{array}{l}\text { Increase in amount of } \\
\text { deprecation }\end{array}$ & $\begin{array}{l}\text { Decrease in amount of } \\
\text { deprecation }\end{array}$ & $\Sigma\left[D A_{i}^{j} \cdot R D_{i}\right]$ & $\begin{array}{l}D A_{i}^{j}-\text { depreciable asset; } \\
R D_{i}-\text { rate of depreciation of the asset }\end{array}$ \\
\hline $\begin{array}{l}\text { Decrease in accounts } \\
\text { receivable }\end{array}$ & $\begin{array}{l}\text { Increase in accounts } \\
\text { receivable }\end{array}$ & $\Sigma\left[\frac{S P \cdot S C A R}{365}\right]$ & $\begin{array}{c}S P-\text { shipped products; } \\
\text { SCAR- speed of collection of accounts } \\
\text { receivable }\end{array}$ \\
\hline Decrease in stock & Increase in stock & $\Sigma\left[Q_{i} \cdot P_{i}\right]$ & $\begin{array}{l}Q_{i} \text {-quantity of goods and materials; } \\
P_{i} \text { - price of goods and materials }\end{array}$ \\
\hline $\begin{array}{l}\text { Increase in short-term } \\
\text { financial liabilities }\end{array}$ & $\begin{array}{l}\text { Decrease of short-term } \\
\text { financial liabilities }\end{array}$ & \multirow{2}{*}{\multicolumn{2}{|c|}{$\begin{array}{l}\text { Factor model is compiled on the basis of types of expenses and } \\
\text { revenue receipts }\end{array}$}} \\
\hline $\begin{array}{l}\text { Increase in amount of } \\
\text { provisions for future } \\
\text { expenses and revenues }\end{array}$ & $\begin{array}{l}\text { Decrease of amount of } \\
\text { provisions for future } \\
\text { expenses and revenues }\end{array}$ & & \\
\hline
\end{tabular}

Table 2. Factors of changesin net cash flow for investment operations.

\begin{tabular}{|c|c|c|c|}
\hline \multicolumn{4}{|c|}{ Factors of changes } \\
\hline Increase of NCF & Decrease of NCF & Factor model & Comment \\
\hline $\begin{array}{l}\text { Increase of revenue from sale } \\
\text { of fixed assets }\end{array}$ & $\begin{array}{l}\text { Decrease of revenue from sale of } \\
\text { fixed assets }\end{array}$ & $\Sigma\left[Q_{i} \cdot P_{i}\right]$ & $\begin{array}{c}Q_{i}-\text { quantity of sold fixed } \\
\text { assets; } \\
S_{i}-\text { price of realization of } \\
\text { fixed assets }\end{array}$ \\
\hline $\begin{array}{c}\text { Increase of revenue from sale } \\
\text { of intangible assets, long-term } \\
\text { financial assetsб repurchased } \\
\text { shares }\end{array}$ & $\begin{array}{c}\text { Decrease of revenue from sale of } \\
\text { intangible assets, long-term } \\
\text { financial assets6 repurchased } \\
\text { shares }\end{array}$ & $\Sigma\left[Q_{i} \cdot P_{i}\right]$ & $\begin{array}{c}Q_{i}-\text { quantity of sold } \\
\text { assets; } \\
P_{i}-\text { price of realization of } \\
\text { fixed assets }\end{array}$ \\
\hline $\begin{array}{l}\text { Increase of amount of interest } \\
\text { and dividends on securities }\end{array}$ & $\begin{array}{l}\text { Decrease of amount of interest } \\
\text { and dividends on securities }\end{array}$ & $\Sigma\left[T A F I_{i} \cdot S F I_{i} \cdot \operatorname{Pr}_{i}\right]$ & $\begin{array}{l}\text { TAFI - the total amount of } \\
\text { financial investments; } \\
S F I_{i} \text { - structure of } \\
\text { financial investments; } \\
P r_{i} \text { - level of profitability } \\
\text { of financial investments }\end{array}$ \\
\hline $\begin{array}{l}\text { Decrease of investments in } \\
\text { purchase of fixed assets }\end{array}$ & $\begin{array}{l}\text { Increase of investments in } \\
\text { purchase of fixed assets }\end{array}$ & $\Sigma\left[Q_{i} \cdot P_{i}\right]$ & $\begin{array}{c}Q_{i}-\text { quantity of purchased } \\
\text { fixed assets; } \\
\mathrm{P}_{i}-\text { cost of purchased } \\
\text { assets }\end{array}$ \\
\hline
\end{tabular}




\begin{tabular}{|c|c|c|c|}
\hline $\begin{array}{l}\text { Decrease of investment in } \\
\text { capital construction }\end{array}$ & $\begin{array}{l}\text { Increase of investment in capital } \\
\text { construction }\end{array}$ & $\Sigma\left[Q_{i} \cdot V P W_{i} \cdot P_{i}\right]$ & $\begin{array}{c}Q_{i}-\text { the number of objects } \\
\text { under construction; } \\
P_{i} \text { - estimated cost of } \\
\text { performed work; } \\
V P W_{i}-\text { volume of } \\
\text { performed work on each } \\
\text { subject }\end{array}$ \\
\hline $\begin{array}{l}\text { Decrease of investment in } \\
\text { purchase of intangible assets }\end{array}$ & $\begin{array}{l}\text { Increase of investment in } \\
\text { purchase of intangible assets }\end{array}$ & $\Sigma\left[Q_{i} \cdot P_{i}\right]$ & $\begin{array}{c}Q_{i}-\text { quantity of purchased } \\
\text { assets; } \\
P_{i}-\text { cost of purchased } \\
\text { assets }\end{array}$ \\
\hline $\begin{array}{l}\text { Decrease of investment in } \\
\text { purchase of long-term } \\
\text { financial assets }\end{array}$ & $\begin{array}{c}\text { Decrease of investment in } \\
\text { purchase of long-term financial } \\
\text { assets }\end{array}$ & \multirow{4}{*}{\multicolumn{2}{|c|}{$\begin{array}{c}\text { Factor model is compiled on the basis of types of } \\
\text { expenses and revenue receipts }\end{array}$}} \\
\hline $\begin{array}{l}\text { Decrease in the number of } \\
\text { repurchased shares of enterprise }\end{array}$ & $\begin{array}{l}\text { Increase in the number of } \\
\text { repurchased shares of enterprise }\end{array}$ & & \\
\hline $\begin{array}{l}\text { Decrease in amount of other } \\
\text { payments }\end{array}$ & $\begin{array}{l}\text { Increase in amount of other } \\
\text { payments }\end{array}$ & & \\
\hline $\begin{array}{l}\text { Increase in amount of other } \\
\text { revenue receipts }\end{array}$ & $\begin{array}{l}\text { Decrease in amount of other } \\
\text { revenue receipts }\end{array}$ & & \\
\hline
\end{tabular}

\section{Dynamics and analysis of cash flow}

After the text edit has been completed, the paper is ready for the template. Duplicate the template file by using the Save As command, and use the naming convention prescribed by your conference for the name of your paper. In this newly created file, highlight all of the contents and import your prepared text file. You are now ready to style your paper; use the scroll down window on the left of the MS Word Formatting toolbar.

Inflows and outflows of cash funds associated with the use of external financingare traditionally reflected in financing activity [4, p. 494].

Results of net cash flow calculations for current, investment and financial operations allow to determine the total net cash flow:

$$
N C F=N C F_{C O}+N C F_{I O}+N C F_{F O}
$$

The advantage of this method is the possibility to identify dynamics of all factors that form net cash flow. However, the use of both direct and indirect methodsin combination to obtain accurate data on the composition and amount of cash funds.

The second stage of the complex analysis of funds is the analysis of cash flowbalance. To assess the degree of uniformity of forming of cash flows and inflows and their synchronicity certain indicators are calculated:

- Standard deviation (Formula 5):

$$
\sigma=\frac{\sqrt{\sum\left(x_{i}-\bar{x}\right)^{2}}}{n}
$$

where $\mathrm{X}_{\mathrm{i}}$ is the value of the $\mathrm{i}$-th indicator;

$\overline{\mathrm{X}}$ - the average value of index.

A large standard deviation value indicates a large spread in the values of presentedsetwith an average value ofset; a small value, respectively, shows that the values in a set are grouped around the average value.

- The coefficient of variation, to determine which formula 6 is used:

$$
V=\frac{\sigma}{\bar{x}} \cdot 100
$$

A collection is considered to be homogeneous if the coefficient of variation does not exceed $33 \%$ [11, p. 137].

- The correlation coefficient is calculated as follows:

$$
r=\frac{\sum x \cdot y-\frac{\sum x \cdot \sum y}{n}}{\sqrt{\left(\sum x^{2}-\frac{\left(\sum x\right)^{2}}{n}\right) \cdot\left(\sum y^{2}-\frac{\left(\sum y\right)^{2}}{n}\right)}}
$$

where $\mathrm{x}$ is the amount of positive cash flow for the ith period;

$y$ is the amount of negative cash flow for the i-th period;

The closer the correlation coefficient is to one, the smaller is spread of fluctuations between values of positive and negative cash flow.

The third stage of the cash flow analysis is the ratio analysis or analysis of cash flow intensity and effectiveness. 
Table 3. Factors of changesin net cash flow for financial operations.

\begin{tabular}{|c|c|c|c|}
\hline \multicolumn{4}{|c|}{ Factors of changes } \\
\hline Increase of NCF & Decrease of NCF & Factor model & Comment \\
\hline $\begin{array}{l}\text { Increase in long-term } \\
\text { loans and borrowings }\end{array}$ & $\begin{array}{l}\text { Decrease in long-term } \\
\text { loans and borrowings }\end{array}$ & \multirow{4}{*}{$\Sigma\left[S_{i} \cdot T_{i} \cdot I_{i}\right]$} & \multirow{4}{*}{$\begin{array}{c}S_{i}-\text { sum of loans and } \\
\text { borrowings; } \\
T_{i}-\text { period (term) of loans } \\
\text { and borrowings; } \\
I_{i}-\text { the interest rate of loan }\end{array}$} \\
\hline $\begin{array}{l}\text { Increase in short-term } \\
\text { loans and borrowings }\end{array}$ & $\begin{array}{l}\text { Decrease in short-term } \\
\text { loans and borrowings }\end{array}$ & & \\
\hline $\begin{array}{c}\text { Decrease of payments on } \\
\text { long-terms loans and } \\
\text { borrowings }\end{array}$ & $\begin{array}{l}\text { Increase of payments on } \\
\text { long-terms loans and } \\
\text { borrowings }\end{array}$ & & \\
\hline $\begin{array}{l}\text { Decrease of payments on } \\
\text { short-terms loans and } \\
\text { borrowings }\end{array}$ & $\begin{array}{l}\text { Increase of payments on } \\
\text { short-terms loans and } \\
\text { borrowings }\end{array}$ & & \\
\hline $\begin{array}{l}\text { Increase in amount of } \\
\text { received dividends and } \\
\text { interest on short-term } \\
\text { financial investments }\end{array}$ & $\begin{array}{l}\text { Decrease in amount of } \\
\text { received dividends and } \\
\text { interest on short-term } \\
\text { financial investments }\end{array}$ & \multirow[t]{2}{*}{$\Sigma\left[T A F I \cdot S F I_{i} \cdot \operatorname{Pr}\right]$} & \multirow{2}{*}{$\begin{array}{l}T A F I \text { - the total amount of } \\
\text { financial investments; } \\
S F I_{i}-\text { structure of financial } \\
\text { investments ; } \\
\operatorname{Pr}_{i} \text { - level of profitability of } \\
\text { financial investments }\end{array}$} \\
\hline $\begin{array}{l}\text { Decrease in amount of } \\
\text { dividends paid to } \\
\text { company shareholders }\end{array}$ & $\begin{array}{l}\text { Increase in amount of } \\
\text { dividends paid to } \\
\text { company shareholders }\end{array}$ & & \\
\hline $\begin{array}{l}\text { Increase in income from } \\
\text { share issue }\end{array}$ & $\begin{array}{l}\text { Decrease in income from } \\
\text { share issue }\end{array}$ & $\Sigma\left[Q_{i} \cdot P_{i}\right]$ & $\begin{array}{l}Q_{i}-\text { quantity of issued assets; } \\
\quad P_{i}-\text { cost of issued assets }\end{array}$ \\
\hline $\begin{array}{l}\text { Increase in amount of } \\
\text { target financing of } \\
\text { revenue receipts }\end{array}$ & $\begin{array}{l}\text { Decrease in amount of } \\
\text { target financing of } \\
\text { revenue receipts }\end{array}$ & \multirow{3}{*}{\multicolumn{2}{|c|}{$\begin{array}{l}\text { Factor model is compiled on the basis of types of expenses and } \\
\text { revenue receipts }\end{array}$}} \\
\hline $\begin{array}{l}\text { Increase in amount of } \\
\text { other revenue receipts }\end{array}$ & $\begin{array}{l}\text { Decrease in amount of } \\
\text { other revenue receipts }\end{array}$ & & \\
\hline $\begin{array}{l}\text { Decrease in amount of } \\
\text { other payments }\end{array}$ & $\begin{array}{l}\text { Increase in amount of } \\
\text { other payments }\end{array}$ & & \\
\hline
\end{tabular}

The intensity of cash flow is characterized by process of its movement, which includes three stages: procurement, production andsaling. The total duration of these stages gives the total length of the operating cycle:

$$
O C=C P G M+C P W P+C P F P+C P A R,
$$

where $C P G M$ is a circulation period of goods and materials;

$C P W P$ is a circulation period of work in progress; $C P F P$ is a circulation period of the finished product; $C P A R$ is a circulation period ofaccounts receivable.

Analysis of time cycle of cash funds circulating allows us to establish on which of the steps there is a delay and to develop activities aimed at the more intensive use of cash funds.
Analysis of cash flow effectiveness is carried out with epyuse of number of factors that are shown in Table IV [12, p. 395; 13, p. 179]

Listed in Table IV coefficients should be analyzed in dynamicswith calculatingof deviations

This technique of cash funds analysis allows to find out, measure and analyze cash flow of an enterprise, as well asoptimize cash funds on the basis of obtained data [14-16].

In the analysis of cash flow of enterprises unbalanced cash flow is identified - an imbalance, prevalence of cash outflow over cash inflow.

Table 4. Indicators of cash flow effectiveness.

\begin{tabular}{|c|c|c|}
\hline Coefficient & Calculation formula & Comment \\
\hline $\begin{array}{c}\text { the efficiency } \\
\text { ratio of cash } \\
\text { flow }\end{array}$ & $R_{e f f}=\frac{N C F}{C F_{o}}$ & $\begin{array}{c}N C F-\text { net cash } \\
\text { flow }\end{array}$ \\
\hline
\end{tabular}




\begin{tabular}{|c|c|c|}
\hline $\begin{array}{c}\text { the adequacy } \\
\text { ratio of cash } \\
\text { flow }\end{array}$ & $R_{a d}=\frac{N C F}{P L B+\Delta S+D P_{i}}$ & $\begin{array}{c}P L B_{i} \text { - payments } \\
\text { on loans and } \\
\text { borrowings; } \\
\begin{array}{c}\Delta S-\text { increase in } \\
\text { stock balance; } \\
D P-\text { dividends } \\
\text { paid }\end{array}\end{array}$ \\
\hline $\begin{array}{c}\text { the efficiency } \\
\text { ratio of cash } \\
\text { flow }\end{array}$ & $R_{\text {liq }}=\frac{C F_{i}}{C F_{o}}$ & $\begin{array}{c}C F_{o}-\text { cash } \\
\text { outflow }\end{array}$ \\
\hline \multirow{2}{*}{$\begin{array}{c}\text { The } \\
\text { profitability } \\
\text { ratio of cash } \\
\text { flow }\end{array}$} & $R_{p r}$ cash inflow $=\frac{N P}{C F_{i}}$ & $\begin{array}{c}C F_{i}-\text { cash } \\
\text { inflow }\end{array}$ \\
\cline { 2 - 3 } & $R_{p r}$ cash flow $=\frac{N F}{\overline{C B}}$ & $\begin{array}{c}\overline{C B}-\text { average } \\
\text { cash balance }\end{array}$ \\
\cline { 2 - 3 } & $R_{p r}$ net cash flow $=\frac{N P}{N C F}$ & $\begin{array}{c}\text { NP - net profit } \\
\text { of company }\end{array}$ \\
\cline { 2 - 3 } & $R_{p r}$ cash oufflow $=\frac{N P}{C F_{o}}$ & $\begin{array}{c}C F_{o}-\text { cash } \\
\text { outflow }\end{array}$ \\
\hline
\end{tabular}

The results cash flow optimization should be reflected in preparation of enterprise cash funds budget for the timely adjustment of cash flow and ensuringsolvency of enterprise.

\section{Practical implementation of the computational model of cash flow optimization}

Grouping of theoretical and practical developments, as well as the results of original researches on this subject was tested on the materials of production machine building company ZAO(privately held corporation) "UUMK", which produced 22 heavy autograders (models A-98 and DZ-122B) in 2012. In 2016 , it is planned to increase production by $30 \%$. The average retail price is going to be 3.6 million rubles with quarterly growth, taking into account projected inflation within $15-17 \%$ (according to the Central Bank of the Russian Federation [17]. Sales budget is presented in Table $\mathrm{V}$

Table 5. Sales budget ZAO "UUMK" for 2016.

\begin{tabular}{|c|c|c|c|c|c|}
\hline Production & $\begin{array}{c}\text { I } \\
\text { quarter }\end{array}$ & $\begin{array}{c}\text { II } \\
\text { quarter }\end{array}$ & $\begin{array}{c}\text { III } \\
\text { quarter }\end{array}$ & $\begin{array}{c}\text { IV } \\
\text { quarter }\end{array}$ & Total \\
\hline \multicolumn{7}{|c|}{ Sales volume, in units } \\
\hline $\begin{array}{c}\text { Autograder } \\
\text { A-98 }\end{array}$ & 3 & 5 & 4 & 4 & 16 \\
\hline $\begin{array}{c}\text { Autograder } \\
\text { DZ-122B }\end{array}$ & 4 & 3 & 3 & 2 & 12 \\
\hline \multicolumn{7}{|c|}{ The unit price, in thousands of RUR } \\
\hline $\begin{array}{c}\text { Autograder } \\
\text { A-98 }\end{array}$ & 4550 & 4778 & 5016 & 5267 & - \\
\hline $\begin{array}{c}\text { Autograder } \\
\text { DZ-122B }\end{array}$ & 2680 & 3095 & 3250 & 3413 & - \\
\hline \multicolumn{7}{|c|}{ Revenue, in thousands of RUR } \\
\hline $\begin{array}{c}\text { Autograder } \\
\text { A-98 }\end{array}$ & 13650 & 23888 & 20066 & 21069 & $\begin{array}{c}78 \\
672\end{array}$ \\
\hline
\end{tabular}

\begin{tabular}{|c|c|c|c|c|c|}
\hline $\begin{array}{c}\text { Autograder } \\
\text { DZ-122B }\end{array}$ & 10720 & 9286 & 9751 & 6825 & $\begin{array}{c}36 \\
582\end{array}$ \\
\hline Total & 24370 & 33174 & 29816 & 27894 & $\begin{array}{c}115 \\
254\end{array}$ \\
\hline
\end{tabular}

Thus, it is planned for 2016 to produce and sale 28 autograders with expected value of $115,3 \mathrm{mln}$. rubles.

After completing sales budget production budget is needed.

The balance of finished goods at the beginning of 2016 is known and is equal to 2 for A-98 model and 1 for DZ-122B model with basic complexion.

Production budget is shown it Table VI.

Table 6. Production budget of ZAO "UUMK", in units.

\begin{tabular}{|c|c|c|c|c|c|}
\hline Production & $\begin{array}{c}\text { I } \\
\text { quarter }\end{array}$ & $\begin{array}{c}\text { II } \\
\text { quarter }\end{array}$ & $\begin{array}{c}\text { III } \\
\text { quarter }\end{array}$ & $\begin{array}{c}\text { IV } \\
\text { quarter }\end{array}$ & Total \\
\hline \multicolumn{7}{|c|}{ Sales } \\
\hline $\begin{array}{c}\text { Autograder } \\
\text { A-98 }\end{array}$ & 3 & 5 & 4 & 4 & 16 \\
\hline $\begin{array}{c}\text { Autograder } \\
\text { DZ-122B }\end{array}$ & 4 & 3 & 3 & 2 & 12 \\
\hline
\end{tabular}

The balance of finished goods at the beginning of year

\begin{tabular}{|c|c|c|c|c|c|}
\hline $\begin{array}{c}\text { Autograder } \\
\text { A-98 }\end{array}$ & 1 & 1 & 1 & 1 & - \\
\hline $\begin{array}{c}\text { Autograder } \\
\text { DZ-122B }\end{array}$ & 1 & 1 & 1 & 1 & - \\
\hline \multicolumn{5}{|c|}{ The balance of finished goods at the end of year } \\
\hline $\begin{array}{c}\text { Autograder } \\
\text { A-98 }\end{array}$ & 2 & 1 & 1 & 1 & - \\
\hline $\begin{array}{c}\text { Autograder } \\
\text { DZ-122B }\end{array}$ & 1 & 1 & 1 & 1 & - \\
\hline $\begin{array}{c}\text { Autograder } \\
\text { A-98 }\end{array}$ & 2 & 5 & 4 & 4 & 15 \\
\hline $\begin{array}{c}\text { Autograder } \\
\text { DZ-122B }\end{array}$ & 4 & 3 & 3 & 2 & 12 \\
\hline
\end{tabular}

The set level of finished goods stock is a prerequisite for trouble-free shipment and rhythm of product supply.

The data on volumes of production allows to start the development of direct material costs. To produce autograders, ZAO "UUMK" buys imported goods and components. Due to depreciation of the national currency rate, the purchase of foreign materials is expensive and, as one of the measures for optimizing company's financial condition is reducing costs, the recommendation will be to purchase goods produced by domestic enterprises.

Material budget is presented in Table VII

In 2015 the total cost of purchasing goods amounted to $64 \mathrm{mln}$. rubles, which is by $30 \%$ higher than value obtained in preparation of material cost budget.

The budget (estimate) of direct material costs is based on the immutability of consumption rates and prices of materials. In the case of changing these settings during budget period values of estimate must be recalculated [18, p. 348].

The next stage is drawning up the budget of direct labour cost. In this budget, we take into account only labour cost of production workers. Average wage of a production worker amounts to 25 thousands of rubles.

The budget of direct labour costs is presented in Table VIII. 
Table 7. Budget of direct material costs of ZAO "UUMK" in 2016.

\begin{tabular}{|c|c|c|c|c|c|}
\hline Autograder A-98 & I quarter & II quarter & III quarter & IV quarter & Total \\
\hline $\begin{array}{l}\text { Quantity of production to } \\
\text { manufacture, in units }\end{array}$ & 2 & 5 & 4 & 4 & 15 \\
\hline $\begin{array}{l}\text { Direct material costs per unit, } \\
\text { in thousands of RUR }\end{array}$ & 2050 & 2153 & 2260 & 2373 & - \\
\hline $\begin{array}{l}\text { Direct material costs, in } \\
\text { thousands of RUR }\end{array}$ & 4100 & 10763 & 9041 & 9493 & 33396 \\
\hline $\begin{array}{l}\text { Material stock at the end of } \\
\text { period, in thousands of RUR }\end{array}$ & 215 & 181 & 190 & 185 & - \\
\hline $\begin{array}{l}\text { Material stock at the } \\
\text { beginning of period, in } \\
\text { thousands of RUR }\end{array}$ & 1230 & 215 & 181 & 190 & - \\
\hline $\begin{array}{l}\text { The amount of cost for } \\
\text { purchasing materials, in } \\
\text { thousands of RUR }\end{array}$ & 3085 & 10728 & 9050 & 9487 & 32350 \\
\hline $\begin{array}{l}\text { Cost of purchasing for } \\
\text { producing } 1 \text { unit, in } \\
\text { thousands of RUR }\end{array}$ & 1543 & 2146 & 2262 & 2372 & - \\
\hline $\begin{array}{c}\text { Quantity of production to } \\
\text { manufacture, in units }\end{array}$ & 4 & 3 & 3 & 2 & 12 \\
\hline $\begin{array}{l}\text { Direct material costs per unit, } \\
\text { in thousands of RUR }\end{array}$ & 1450 & 1523 & 1599 & 1679 & - \\
\hline $\begin{array}{l}\text { Direct material costs, in } \\
\text { thousands of RUR }\end{array}$ & 5800 & 4568 & 4796 & 3357 & 18520 \\
\hline $\begin{array}{l}\text { Material stock at the end of } \\
\text { period, in thousands of RUR }\end{array}$ & 91 & 96 & 67 & 218 & - \\
\hline $\begin{array}{l}\text { Material stock at the } \\
\text { beginning of period, in } \\
\text { thousands of RUR }\end{array}$ & 1450 & 91 & 96 & 67 & - \\
\hline $\begin{array}{l}\text { The amount of cost for } \\
\text { purchasing materials, in } \\
\text { thousands of RUR }\end{array}$ & 4441 & 4572 & 4767 & 3507 & 17288 \\
\hline $\begin{array}{l}\text { The amount of cost for } \\
\text { purchasing materials, in } \\
\text { thousands of RUR }\end{array}$ & 1110 & 1524 & 1589 & 1754 & - \\
\hline $\begin{array}{l}\text { Total amount of costs on } \\
\text { purchasing materials, } \\
\text { thousand of RUR }\end{array}$ & 7527 & 15300 & 13817 & 12995 & 49638 \\
\hline
\end{tabular}

Table 8. Budget of direct labour costs of ZAO "UUMK" in 2016.

\begin{tabular}{|c|c|c|c|c|c|}
\hline Autograder A-98 & I quarter & $\begin{array}{c}\text { II } \\
\text { quarter }\end{array}$ & $\begin{array}{c}\text { III } \\
\text { quarter }\end{array}$ & $\begin{array}{c}\text { IV } \\
\text { quarter }\end{array}$ & Total \\
\hline $\begin{array}{c}\text { Quantity of production to } \\
\text { manufacture, in units }\end{array}$ & 2 & 5 & 4 & 4 & 15 \\
\hline $\begin{array}{c}\text { Direct labour costs per } \\
\text { unit, in thousands of RUR }\end{array}$ & 420 & 422 & 1697 & 1705 & 6353 \\
\hline $\begin{array}{c}\text { Amount of direct labour } \\
\text { costs, in thousands of } \\
\text { RUR }\end{array}$ & 840 & 2111 & 3 & 2 & 12 \\
\hline $\begin{array}{c}\text { Quantity of production to } \\
\text { manufactu-re, in units }\end{array}$ & 4 & 3 & 232 & 233 & - \\
\hline $\begin{array}{c}\text { Direct labour costs per } \\
\text { unit, in thousands of RUR }\end{array}$ & 230 & 231 & 697 & 467 & 2777 \\
\hline $\begin{array}{c}\text { Amount of direct labour } \\
\text { costs, in thousands of } \\
\text { RUR }\end{array}$ & 920 & 693 & 2394 & 2172 & 9130 \\
\hline $\begin{array}{c}\text { Total amount of labour } \\
\text { costs, in thousands of } \\
\text { RUR }\end{array}$ & 1760 & 2804 & & 23 & - \\
\hline
\end{tabular}

Additionally, to optimize cash flow of ZAO "UUMK", it is necessary to make plans for payments to suppliers for materials and payments of buyers for delivered goods. According to cash inflow plan, the 
payment for delivered products will be based on advance payment in the amount of $70 \%$ with defer of payment (3 months). There also will be repayed receivables of 2015 .

Cash inflow plan is shown in Table IX.

Table 9. Cash inflow plan for realized products of ZAO "UUMK" in 2016

\begin{tabular}{|c|c|c|c|c|c|}
\hline Value & $\begin{array}{c}\text { I } \\
\text { quart } \\
\text { er }\end{array}$ & $\begin{array}{c}\text { II } \\
\text { quart } \\
\text { er }\end{array}$ & $\begin{array}{c}\text { III } \\
\text { quart } \\
\text { er }\end{array}$ & $\begin{array}{l}\text { IV } \\
\text { quart } \\
\text { er }\end{array}$ & Total \\
\hline \multicolumn{6}{|c|}{$\begin{array}{l}\text { Accounts receivables at the beginning of } 2016 \text { : } \\
14635, \text { thousand RUR }\end{array}$} \\
\hline $\begin{array}{c}\text { Revenue } \\
\text { from sales } \\
\text { of products, } \\
\text { thousand } \\
\text { RUR }\end{array}$ & $\begin{array}{c}24 \\
370\end{array}$ & $\begin{array}{c}33 \\
174\end{array}$ & $\begin{array}{c}29 \\
816\end{array}$ & $\begin{array}{c}27 \\
894\end{array}$ & $\begin{array}{l}115 \\
254\end{array}$ \\
\hline $\begin{array}{l}\text { Payments } \\
\text { for } \\
\text { products, } \\
\text { thousand } \\
\text { RUR }\end{array}$ & $\begin{array}{c}1852 \\
3\end{array}$ & $\begin{array}{c}3272 \\
8\end{array}$ & $\begin{array}{c}3375 \\
0\end{array}$ & $\begin{array}{c}3139 \\
8\end{array}$ & $\begin{array}{l}116 \\
398\end{array}$ \\
\hline \multicolumn{5}{|c|}{$\begin{array}{c}\text { Accounts receivables at the end of } 2016, \\
\text { thousand RUR }\end{array}$} & 13490 \\
\hline
\end{tabular}

According to plan of cash flow, by the end of 2016 accounts receivable can be equal to $13,5 \mathrm{mln}$. rubles, which is $9 \%$ less than in 2015 .

Table 10. Cash inflow plan for realized products of ZAO "UUMK" in 2016.

\begin{tabular}{|c|c|c|c|c|c|}
\hline Value & $\begin{array}{c}\text { I } \\
\text { quart } \\
\text { er }\end{array}$ & $\begin{array}{c}\text { II } \\
\text { quart } \\
\text { er }\end{array}$ & $\begin{array}{l}\text { III } \\
\text { quart } \\
\text { er }\end{array}$ & $\begin{array}{c}\text { IV } \\
\text { quart } \\
\text { er }\end{array}$ & Total \\
\hline \multicolumn{5}{|c|}{$\begin{array}{c}\text { Accounts payable at the beginning of } 2016, \\
\text { thousand RUR }\end{array}$} & 20735 \\
\hline $\begin{array}{l}\text { Material } \\
\text { costs, } \\
\text { thousand } \\
\text { RUR }\end{array}$ & 7664 & $\begin{array}{c}15 \\
437\end{array}$ & $\begin{array}{c}13 \\
954\end{array}$ & $\begin{array}{c}13 \\
132\end{array}$ & 50186 \\
\hline $\begin{array}{l}\text { Payments } \\
\text { for } \\
\text { products, } \\
\text { thousand } \\
\text { RUR }\end{array}$ & 5905 & $\begin{array}{c}13 \\
128\end{array}$ & $\begin{array}{c}17 \\
288\end{array}$ & $\begin{array}{c}19 \\
023\end{array}$ & 55344 \\
\hline \multicolumn{5}{|c|}{$\begin{array}{c}\text { Accounts payable at the end of } 2016 \\
\text {,.thousand RUR }\end{array}$} & 15577 \\
\hline
\end{tabular}

Thus, a decrease in accounts payable will amount to $5 \mathrm{mln}$. rubles, which will significantly affect the liquidity of enterprise.

Cash flow budget is a planning document that includes expected inflow and outflow of cash funds during the planned period. The inflow is formed on the basis of sources of cash funds income and outflow - on the basis of directions of use [19, p. 19].

Cash flow budget of current operations is presented in Table XI.
Table 11. Cash flow budget of ZAO «UUMK», current operations in 2016.

\begin{tabular}{|c|c|c|c|c|c|}
\hline Value & $\begin{array}{c}\text { I } \\
\text { quart } \\
\text { er } \\
\end{array}$ & $\begin{array}{c}\text { II } \\
\text { quart } \\
\text { er } \\
\end{array}$ & $\begin{array}{c}\text { III } \\
\text { quart } \\
\text { er } \\
\end{array}$ & $\begin{array}{c}\text { IV } \\
\text { quart } \\
\text { er } \\
\end{array}$ & Total \\
\hline \multicolumn{6}{|c|}{ CASH FLOW FROM CURRENT OPERATIONS } \\
\hline TOTAL & 18 & 32 & 33 & 31 & 116 \\
\hline INCOME & 523 & 728 & 750 & 398 & 398 \\
\hline $\begin{array}{l}\text { Including } \\
\text { sales of } \\
\text { products, } \\
\text { goods, work } \\
\text { and services }\end{array}$ & $\begin{array}{c}18 \\
523\end{array}$ & $\begin{array}{c}32 \\
728\end{array}$ & $\begin{array}{c}33 \\
750\end{array}$ & $\begin{array}{c}31 \\
398\end{array}$ & $\begin{array}{l}116 \\
398\end{array}$ \\
\hline $\begin{array}{l}\text { TOTAL } \\
\text { PAYMENT } \\
\text { S, including: }\end{array}$ & $\begin{array}{c}14 \\
039\end{array}$ & $\begin{array}{c}24 \\
219\end{array}$ & $\begin{array}{c}28 \\
683\end{array}$ & $\begin{array}{c}30 \\
014\end{array}$ & -96954 \\
\hline $\begin{array}{l}\text { payments for } \\
\text { goods, work, } \\
\text { services }\end{array}$ & 5905 & $\begin{array}{c}13 \\
128\end{array}$ & $\begin{array}{c}17 \\
288\end{array}$ & $\begin{array}{c}19 \\
023\end{array}$ & -55344 \\
\hline $\begin{array}{c}\text { labour } \\
\text { payments }\end{array}$ & 2950 & 3998 & 3592 & 3375 & -13915 \\
\hline $\begin{array}{l}\text { payments of } \\
\text { interest on } \\
\text { loans and } \\
\text { borrowings }\end{array}$ & 380 & 380 & 380 & 380 & -1520 \\
\hline $\begin{array}{l}\text { payments of } \\
\text { taxes and } \\
\text { duties }\end{array}$ & 126 & 2011 & 2698 & 2487 & -7322 \\
\hline $\begin{array}{c}\text { other } \\
\text { payments } \\
\text { and transfers }\end{array}$ & 4678 & 4701 & 4725 & 4749 & -18853 \\
\hline $\begin{array}{c}\text { Cash flow } \\
\text { balance of } \\
\text { current } \\
\text { operations } \\
\end{array}$ & 4483 & 8509 & 5068 & 1384 & 19444 \\
\hline
\end{tabular}

The expected net cash flow is positive due to increase in entity's revenue, a decrease of production cost because of use of domestic materials, optimization of customer payments for purchased products, as well as payments to suppliers for materials supplied. Cash flow of financial and investment operations are reflected in cash flow budget as they have a quick turnover, big amounts and short repayment terms [20]. Therefore, the budget will be not on a quarterly, but on a year basis. The cash flow budget for investment and financial operations is shown in Table XII.

Table 12. Cash flow budget of ZAO "UUMK", investment and financial operations in 2016.

\begin{tabular}{|c|c|}
\hline Value & Total \\
\hline \multicolumn{2}{|c|}{ CASH FLOW FROM INVESTMENT OPERATIONS } \\
\hline $\begin{array}{c}\text { TOTAL INCOME } \\
\text { Of loans }\end{array}$ & 4120 \\
\hline Including interest on financial investment, return & 4120 \\
\hline $\begin{array}{c}\text { Tncluding payment for purchase of fixed } \\
\text { assets(including income bearing investments } \\
\text { tangible assets) and intangible assets }\end{array}$ & 3540 \\
\hline Payments for financial investments & 300 \\
\hline $\begin{array}{c}\text { The result of cash flow from investment } \\
\text { operations }\end{array}$ & -1 \\
\hline
\end{tabular}




\begin{tabular}{|c|c|}
\hline \multicolumn{2}{|c|}{ CASH FLOW FROM FINANCIAL OPERATIONS } \\
\hline TOTAL INCOME & $\begin{array}{c}11 \\
200\end{array}$ \\
\hline including loans and borrowings & $\begin{array}{c}11 \\
200\end{array}$ \\
\hline TOTAL PAYMENTS & $\begin{array}{c}11 \\
028\end{array}$ \\
\hline including repayment of loans and borrowings & $\begin{array}{l}-10 \\
822\end{array}$ \\
\hline Payment of dividends & -206 \\
\hline $\begin{array}{c}\text { The result of cash flow from financial } \\
\text { operations }\end{array}$ & 172 \\
\hline
\end{tabular}

In 2016 ZAO "UUMK" plans to acquire a machine tool that will be able to fo multioperational machining of details with complex configuration. In addition to purchase of this machine, the enterprise plans to carry out a repair of shop premises. For this purpose, it is planned to take an investment loan in the sum of 11 $\mathrm{mln}$. rubles with repayment term of 18 months and an average rate of $15 \%$.

In 2015 the company acquired debt securities that provide income in 2016.

The expected net cash flow from investment and financial operations is positive. Total net cash flow is equal to 20196 thousand rubles, which will make it possible for organization $t$ carry out further modernization of products at the expense of its own funds without involving expensive external sources of financing.

Conclusion

The monitoring of scientific literature on optimizing cash flow, as well as testing of the hypothesis of research on materials of industrial enterprise allowed to develop a method of cash flow optimization for of ZAO "UUMK" company, which is one of the four largest manufactures of road machines along with ZAO "Bryanskiy arsenal", ZAO "ChSDM", ZAO "Zavod Dormash" and ZAO "PO "Irmash".

Financial analysis showed that the company is financially unstable at the end of 2015 with a high probability of bankruptcy and loss of solvency.

Authors propose a model of cash funds optimization included in budgeting of ZAO "UUMK" that suggests:

- the use of "accelerating-decelerating pay transactions" which provides acceleration of accounts receivable turnover - payment for delivered products will be based on $70 \%$ advance payment, defer of payment (3 months) and slowing down payments to suppliers and contractors - 50\% will be paid on condition of advance payment with deferred of payment ( 6 months) in the short term:

- the use of financial instruments for both raising and allocating cash funds, reduction of production cost by reducing costs of enterprise in the long term.

The performed analysis of ZAO "UUMK" targets led to conclusion about the appropriateness of using the optimization model based on obtained data that will provide:
1) positive trend in revenue of $9 \mathrm{mln}$. rubles due to increase in production of autograders which, as well as increase in machinery prices;

2) decrease of $15 \mathrm{mln}$. rubles in production cost;

3) the use of "accelerating-decelerating pay transaction system" that will reduce accouts receivable by $1 \mathrm{mln}$. Rubles, accounts payable - by 5 mln. rubles;

4) Net cash flow and net income suggest that enterprise has its own sources for self-financing of its activities.

Thus, the hypothesis of cash flow optimization through budgeting system was confirmed during the practical experiment in industrial plant.

The work was supported by Act 211 Government of the Russian Federation, contract № 02.A03.21.0011.

\section{References}

1. K.S. Lorek, G.L. Willinger, Source of the DocumentAccounting Review, 71(1), 81-102 (1996)

2. P. Martins, Lecture Notes in Economics and Mathematical Systems, 682, 115-121 (2016). http://www.scopus.com/inward/record.url?eid=2s2.0-

$84951798889 \&$ partnerID $=40 \& \mathrm{md} 5=1$ deebebbbca bc6ec4fa7ef9ce98ce7fb.

3. W.-N. Chen, J. Zhang, H.S.-H. Chung, R.-Z. Huang, Liu, IEEE Transactions on Systems, Man and Cybernetics Part C: Applications and Reviews, 40(1), 5196736, 64-77 (2010). http://www.scopus.com/inward/record.url?eid=2s2.0-

$73049110195 \&$ partnerID $=40 \& \mathrm{md} 5=52 \mathrm{~b} 48 \mathrm{a} 883 \mathrm{f} 1$ a0088f50dc5072c086e3a

4. G.V. Savitskaya, Analysis of economic activity of enterprise (New knowledge, Moscow, 2011)

5. V.V. Kovalev, Financial analysis: methods and procedures (Finance and Statistics, Moscow, 2012)

6. A.D. Sheremet, Comprehensive analysis of economic activity: Textbook (INFRA-M, Moscow, 2011).

http://www.books.ru/books/analiz-finansovykhoperatsii-metody-modeli-tekhnika-vychislenii32980/ (C) Books.ru.

7. E.V. Sanakoyev, Cash flows of companies and their optimization 2011 (Vladikavkaz). http://www.dissercat.com/content/denezhnyepotoki-predpriyatii-i-ikhoptimizatsiya\#ixzz4415Quda.

8. D.A. Novolodsky, Improving cash flow management system in enterprise (Ph.D. Dissertation, Novosibirsk, 2004). http://www.dissercat.com/content/sovershenstvov anie-sistemy-upravleniya-potokami-denezhnykhsredstv-na-predpriyatii\#ixzz4417T96uO. 
9. A.A. Sinkina, Cash Flow Management: A case study of industrial enterprises in the Kemerovo region (Kemerovo, 2006)

10. http://www.dissercat.com/content/upravleniedenezhnymi-potokami-na-primerepromyshlennykh-predpriyatii-kemerovskoioblasti\#ixzz4419KraVv.

11. B. Kolass, Management of financial activity of enterprise: problems, concepts and methods: manual (Economics, Moscow, 2013)

12. Economic Analysis: Textbook for universities (Unity-Dana, Moscow, 2011)

13. M.A. Vahrushina, Financial Statement Analysis: Textbook (University textbook, Moscow, 2011)

14. A.T. Gasparyan, T.N. Myznikova, Proc. Young researcher, 291-295 (2015)

15. L.G. Zaharova, T.N. Myznikova, Proc. Trends and prospects of financial and economic development of Russia, 50-52 (2015)
16. T.B. Krasnenko, T.N. Myznikova, Optimization of cash flows in company. In the collection: Modern society: scientific view of young people Collection of articles and abstracts of the XI International scientific and practical conference of students, undergraduates and graduate students, 86-90 (2015)

17. The Central Bank of the Russian Federation. Inflation in the consumer market. http://www.cbr.ru/statistics/?PrtId=macro_sub.

18. E.Y. Dobrovolsky, Budgeting: step by step (Peter, Saint-Petersburg, 2013)

19. On Accounting: Federal Law of December 6, 2011 no. 402-FZ, as amended on April 4, 2014, legal reference system ConsultantPlus.

20. S.A. Sterlyadev, Modern scientific researches and innovations, 8, 19 (2014) 